\title{
Adolescents' Gender And Age As Correlates of Career Choice Among Secondary School Students In Southwest Nigeria
}

\author{
FABUNMI Joseph (Ph.D) \\ Faculty of Education, Ekiti State University, Ado-Ekiti \\ ADEDAYO Julius 0. (Ph.D) \\ Faculty of Education, Ekiti State University, Ado-Ekiti
}

\begin{abstract}
The issues of gender and adolescents age difference as they relate with choice of career among secondary school students in southwest Nigeria are the core concerns of this paper. The study was an empirical one which focused on senior secondary school students who are in their penultimate years in the secondary school, where subject selection takes place based on their career interests. A total of 100 SSII students responded to the study, who were selected through a multistage random sampling technique. The instrument, tagged "Student Career Inventory (SCI) was constructed by the researchers and validated against two similar instruments namely - the Vocational Interest Inventory (VII) and Career Inventory Survey (CIS) for content and construct validities using factor analysis. This yielded coefficients of 0.58 and 0.63 respectively. The same process of factor analysis was used to test the reliability of the instrument which was found to be reliable with a coefficient of 0.966 . The finding of the study showed a significance difference in the choice of career between male and female students, but not significant as with respect to age difference between 15 and 17 years. Based on this, it was recommended among others that gender issue should be put into consideration when career choice is to be treated.
\end{abstract}

\section{INTRODUCTION}

Choosing a career is a delicate decision that cannot be taken in a hurry. If adolescents are not well guided, lots of misdirected decisions may be taken which may have grave implications on the young person that should have been helped to achieve a career choice success. If care is not taken, an adolescent may emphasizes interest far above his ability and therefore makes decision that may be inappropriate at the end of the day.

Nuhm \& Irene (2012) posited that there are careers that have very great appealing to adolescents. At the initial stage, such careers as soldering, banking, medicine, and engineering have high attraction, little concern is given to the antecedent pre-qualification requirements, be it social, academic or even the environmental demands.

In Nigeria, adolescents begin the journey to career choice as soon as they choose their subjects early in SS II, the penultimate year to writing their final certificate examinations, having spent the previous year consolidating in the arts, social science or pure science subjects. The performances at the end of SS I inform the school Counsellor to stream him to arts, social science or science classes.

Ecdes (1994) and Gottfredson (2005) submitted at young adults' awareness of their gender and their social class influences their perceptions of career aspirations. Thus, the son of a monarch may be worried of the career he choose eventually. The adolescence is a period when future career forms a major concern of the adolescents (Fabunmi, 2014). However, initial 
decisions are flexible and easily changeable at later dates with increased awaresness and information. Akinboye (1997) opined that the adolescence is the time when the thinking, feelings, motivation, aspirations, desires and reactions change drastically from that of childhood towards that of the adult.

In Nigeria some decades ago, more especially in the Southwest, adolescent's choice of career was basically determined by the parents. The child woke up one morning only to be informed that he/she will be learning tailoring, blacksmithing, buying and selling, etc at so and so workplace the following day, week or at so and so time. Often than not, the child had little or no choice to question the decision of his/her parents, but to comply. Only on very few occasions would such a child say no. Rejection of parents' decisions was rare, however, it could not be totally ruled out. This was when actually western education was not yet a common phenomenon. The parents' directives at such decisions were basically stereotypical of the sex of the child. It was unheard of that for a father to ask the girl-child to go and learn carpentry, brick layering or lumbering, or any muscular-typical jobs. Ladies were rather directed to tailoring (lady's sewing machines were even fashioned differently from those of men). The harder jobs were reserved for boys who were believed to be stronger (Salami, 2008; Owuamanam, 1982).

As time changed, western education took over and such decisions were no longer trusted into the hands of the un-informed parents. Career decision now took a drastic departure from the traditional parental fiats. Even though, research has proved that parents still wield a lot of influence on their children career choice, the final decision devolves on the child himself, who must have been thoroughly convinced before taking the final decision. Some children willing follow their parent's occupation because they just develop into it, and love what their parents do, and just simply key in their interests. Others respond to taking a liking to influences from peers, role models, information from prints and electronic media. Even today, stereotype barriers were still very strongly felt in the societies.

The impact of gender in career choice seems to manifest among the adolescents. Denga (1983) posited that robust careers were mainly considered to be the reservation of boys, while he girls usually take to trading, nursing, secretarial services and catering. He further stated that boys commonly take to engineering, medicine, law, computer studies and some other technical skilled trade while the girls shy away from them as well as subjects like mathematics, physics, surveying and the like that could lead to 'robust careers'. Quite a number of people believe in gender stereotyping choice of career because of the perception of the local people concerning what a boy or a girl can do for a living. Today, it is generally agreed that a female engineer, or lawyer or medical doctor is as effective as any male counterpart in the same profession (Denga, 1993; Egunjobi, 2006).

Gender difference in occupational choices still exists in many socio-cultural settings far beyond the shores of Africa. This in fact is what educational researchers strive to control. In the United Kingdom, no specific job is reserved for either the male or the female gender (Brain, 2013).

The university admission into various courses are said to be close to parity for both boys and girls, but gender equality in job selections or societal role is far from parity. Brain (2013) observed from a survey conducted across the U.K, only $20 \%$ of board of a particular company was women. He claimed that this was not the design, it just was the reality. He submitted that few of the companies were headed by women. As usual, this may not be far from the traditional roles of women in the society which made them more of the home custodians than their men 
counterparts. However, many cultures, if not all, still have to strive for gender balance in many fields and working circumstances, more so when nature's endowment have stipulated roles for the male and the female e.g in pregnancy and child rearing, without hormonal implantation which in itself is unnatural.

The age of the adolescent has implication for choosing a career. Many researchers are of the opinion that careers should be introduced to children in their early teen i.e. age 13 or 14years. Career decisions at this time are very temporary and unrealistic. Most often, the potential of the child cannot yet be ascertained. It is still a time of career illusion and uncertainties. The usefulness of the career information at this period can only be for both awareness and counseling. It could be for helping the young adolescent to begin to have a focus for the future career he may like to engage in, and the various pre-requisite qualifications for them. The age range of 13 to 14 years is a period when the child is just graduating from fantasies to the tentative period of realities. The actual age of reality begins at about age 15 years as far as careers is concerned (Ginzberg, 1951). These days in Nigeria, especially the Southwestern parts, children in the school certificate class are on the average age of 16 years. It means students mature earlier for decision making since many of them transit into the tertiary institutions almost immediately after writing their secondary school final examinations. His presupposes that they have to take career decisions earlier than expected. This is a clear case for career counseling at about age 13 to 14 years. It is a good time to sharpen a child's perspective in respect of what the world of works portend for their future. It is a time to start thinking of what one loves to do and how to get started.

\section{METHODOLOGY}

The study adopted a descriptive design of the survey type. The targeted population was the SS II students across schools in Southwest, Nigeria, out of which 120 students were sampled for the study across four randomly selected states in the area. A multistage random sampling technique was employed which took care of the school of the schools' ownership i.e. Federal, state and private-owned ones. Purposive selections were made on the schools to accommodate equal proportion in the selected states.

The study instrument was a self-constructed inventory tagged "Students Career Inventory" (SCIn), following the pattern of Holland's typology - the Holland`s six. The 6 subscales classification of Holland "RAISEC" was adapted to 7 subscales as RAISOAC viz: R - Realistic, I Investigative, A - Artistic, S - Social, 0 - Outgoing, instead of E - for Enterprising, A - Authority and $\mathrm{C}$ - conventional. In essence, outgoing and authority are the breakdown of enterprising, while A - for authority takes care of the group of people who have a knack for the various uniformed jobs like soldering, policing etc. This is a group that loves to wield authority with the backing of the government authority.

The instrument was subjected to content and construct validity and reliability adequacy. Factor analysis was employed to take care of the validity and reliability of the instruments. The internal consistency of the instrument was further confirmed by convergent validity whereby the instrument was validated against the "Vocational Interest Inventory" (VII) by Bakare, (1977) and the "Career Interest Survey" (CIS). The analysis returned the results of $r=0.50$ and 0.63 respectively. 1000 questionnaires were administered but only 990 were retrieved. The overall reliability was $r=0.766$, a value considered to be reliable.

\section{HYPOTHESES TESTING}

Hypothesis 1: There will be no significant difference in career interest of male and female students of senior secondary schools. 
Table 1: Test of significance of sex biasness in career choice

\begin{tabular}{|c|c|c|c|c|c|c|c|}
\hline & Sex & $\mathrm{N}$ & Mean & Df & t-cal & t-tab & $\begin{array}{l}\text { Significance } \\
\text { Level }\end{array}$ \\
\hline Realistic & $\begin{array}{l}M \\
F\end{array}$ & $\begin{array}{l}581 \\
501\end{array}$ & $\begin{array}{l}32.1736 \\
25.5289\end{array}$ & 1080 & 6.683 & 1.96 & $.000^{*}$ \\
\hline Investigative & $\begin{array}{l}\mathrm{M} \\
\mathrm{F}\end{array}$ & $\begin{array}{l}581 \\
501\end{array}$ & $\begin{array}{l}35.1015 \\
32.0299\end{array}$ & 1080 & 4.989 & 1.96 & $.000^{*}$ \\
\hline Artistic & $\begin{array}{l}\mathrm{M} \\
\mathrm{F}\end{array}$ & $\begin{array}{l}581 \\
501\end{array}$ & $\begin{array}{l}32.5577 \\
31.9681\end{array}$ & 1035 & 0.950 & 1.96 & .342 \\
\hline Social & $\begin{array}{l}\text { M } \\
\mathrm{F}\end{array}$ & $\begin{array}{l}581 \\
501\end{array}$ & $\begin{array}{l}31.8158 \\
31.0758\end{array}$ & 1049 & 1.221 & 1.96 & .222 \\
\hline Outgoing & $\begin{array}{l}M \\
F\end{array}$ & $\begin{array}{l}581 \\
501\end{array}$ & $\begin{array}{l}31.3494 \\
29.3074\end{array}$ & 1080 & 3.773 & 1.96 & $.000^{*}$ \\
\hline Authority & $\begin{array}{l}\mathrm{M} \\
\mathrm{F}\end{array}$ & $\begin{array}{l}581 \\
501\end{array}$ & $\begin{array}{l}36.7504 \\
34.9760\end{array}$ & 999 & 2.540 & 1.96 & $.011^{*}$ \\
\hline Conventional & $\begin{array}{l}\mathrm{M} \\
\mathrm{F}\end{array}$ & $\begin{array}{l}581 \\
501\end{array}$ & $\begin{array}{l}37.8864 \\
35.4830 \\
\end{array}$ & 1080 & 3.291 & 1.96 & $.001^{*}$ \\
\hline $\begin{array}{lr}\text { Students } & \text { Career } \\
\text { Scale } & \text { Interest } \\
\text { (Average) } & \\
\end{array}$ & $\begin{array}{l}\mathrm{M} \\
\mathrm{F}\end{array}$ & $\begin{array}{l}581 \\
501\end{array}$ & $\begin{array}{l}237.6351 \\
223.3693\end{array}$ & 1080 & 14.070 & 1.96 & $.000^{*}$ \\
\hline$* \mathrm{P}<0.05$ & & & & & & & \\
\hline
\end{tabular}

The table above shows an overall sex biasness as significant. The $t$ - calculated (14.07) was higher than the $t$ - table (1.96). Out of the 7 subscales, all but 2 demonstrated high degrees of sex biasness i.e. the Artistic and the Social. The overall result (like almost all the subscales) was significant beyond 0.001 (i.e. at $\mathrm{p}<0.05$ ). The hypothesis is hereby rejected, which means that there is a significant difference in the students' choice of career interest with respect to gender difference.

Hypothesis 2: Age difference within 15 - 17 years will not significantly affect students' choice of career interest.

Table 2: Analysis of variance of age difference between 15 to 17 years old

\begin{tabular}{|l|c|c|c|c|c|}
\hline Variables & Df & $\begin{array}{c}\text { Mean } \\
\text { Square }\end{array}$ & F-cal & F-tab & Sigt \\
\cline { 1 - 3 } $\begin{array}{l}\text { Between } \\
\text { group }\end{array}$ & 4 & 6850.350 & & & \\
\cline { 1 - 3 } Within group & 985 & 3360.471 & 2.047 & 2.99 & 0.086 \\
\cline { 1 - 3 } Total & 989 & & & & \\
\hline
\end{tabular}

From the table 2above, F - calculated (2.047) is less than F - table (2.99).The multiple comparison table shows that within the range of the ages of 15 to 17 years, there is no significance difference in the career interest of students. The hypothesis that age within the bracket of age difference 15 to 17 will not significantly affect choice in career interest is therefore not rejected.

\section{DISCUSSION}

The finding of the study showed that sex-biasness and the career aspirations differ. From the seven subscales, only the social and the Artistic do not reflect sex-biasness. All other subscales indicate that the female gender do not view all jobs the same way their male counterparts view them. This result shows that gender stereotyping is still the order of the day among the 
adolescents as postulated earlier in this study. This finding is in line with researchers like Holland $(1994,1997)$ who posited that men may scpore high on the "realistic" and "investigative" subscales while ladies may score high on the "social" and "conventional". In the same vein, Denga(1983) submitted that robust careers were mainly considered to be the reservation of boys while girls tend to favour occupations that relate trading, nursing, secretarial duties and catering.

The study also revealed that the ages of the adolescents within 15 - 17 years do not significantly affect the way they perceive the various worlds of work. This result agrees with Salami's (2008) observation who found no significant influence as regards to gender on the maturity of adolescent in the choice of career. The 15 years old SS II students do not see any job differently from one another. If they have access to information flow, it has not started to manifest within the ages investigated. It has been suggested that career stability begins to be seen between ages of 20-22 years. By this time, they may have entered the tertiary institution, studying for a career. For between ages 16-18 year old, they will be obtaining admission forms into the university.

\section{CONCLUSION}

Based on the findings of the study, it can be concluded that:

i. there is a significant difference in career interest leading to career choice between the boys and girls.

ii. ages of the adolescents between 15 and 17 have no significant influence on their career choice.

\section{RECOMMENDATIONS}

The following were recommended on the basis of the study:

i. School Counsellors should consider gender issue when career choice is to be treated. Good counseling would guarantee career stability in future.

ii. Employers should give enough incentive to nursing mothers to enable them play down on the various difficulties encountered as a result of combining daily work duties with child rearing.

\section{References}

Bakere, C. G. (1977). Vocational interest inventory scale (VII), Psychological Research

Elspeth, J. R., Hills \& James A. G. (2014). Career decisions and gender: the illusion of choice

Ginzerg, (1951). Towards a theory of occupational choice. Occupations, 30,491-494.

Hassan, M. (2008). Influence of parents occupation, gender and school location on vocational Interest among senior secondary II students in Borno State, Nigeria, Educational psychology.

Hills, E.J.R. \& Giles, J.A. (2014). Career decisions and gender: the illusion of choice.

Holland, J. L. (1959). A theory of vocational choice. Journal of Counselling Psychology, (6)35-44.

Holland, J. L. (1997). Making vocational choice- A theory of vocational personalities and work environment (3rd Ed.) Odessa, FL. Psycological Assessment Resources

Irne, D. \& Nuhm, M.S. (2012). Gender as a factor in the career choice readiness of senior secondary school students in Ilorin Metropolis of Kwara State of Nigeria. Journals of Humanities and Social Science, 2(14). 
Joseph, F., \& Olu, A. J. (2017). Adolescents' Gender And Age As Correlates of Career Choice Among Secondary School Students In Southwest Nigeria. Advances in Social Sciences Research Journal, 4(4) 157-162

Mbuzar, A. (2002). Relationship between family background and occupational choice of senior secondary school students, Borno State, Nigeria.

Mohammed, H. (2008). Influence of parents occupation, gender and school location on vocational interest among senior secondary school II students in Borno State of Nigeria. Educational Psychology

Reichheld \& Satmetrix System Incorporated (2013). A Brain and Company Managing Consultants.

Richard S.Sharf(2006) Applying Career Development Theory To Counselling.

Salami, S.O. (2008). Gender, identity status and a career maturity of adolescents in Southwest Nigeria. Departmet of Guidance \& Counseling, University of Ibadan, Nigeria, Journal Social Sciences (1691) 35-49.

Tayo Olajubu Olufunmilayo(2014) Gender Streotyping and women career centre development in Nigeria Adekunle Ajasin University, Akungba Akoko, Nigeria. Journal Of Poverty, Investment and Development-An open Access Internatuional Journal vol4,2014. 